\title{
PERILAKU INVESTOR DI PASAR MODAL INDONESIA
}

\author{
Sumani \\ sumani@atmajaya.ac.id \\ Christine Winstinindah Sandroto \\ christine.wins@atmajaya.ac.id \\ Indah Mula \\ Fakultas Ekonomi, Universitas Katolik Indonesia Atma Jaya Jakarta
}

\begin{abstract}
The objective of this research is to classify thetype of individual investors in the Indonesia capital market. The purpose of classification is to provide an overview for securities firms about the profile of individual investors in the Indonesia capital market, this classification will also provide overview for individual investors on their investment habits, so they can encourage good trading habits and make the investor obtain good performance from the investment. From the profile, we provide guidelines to incorporate Behavioral Finance into asset allocation design which will better serve the investor's best interest. The result shows that Indonesia individual investors tend to be irrational in investing, where they can be classified into two major groups: the first is the group confident big traders who have high confidence and high control, and the highest value of the portfolio. The second group which is loss averse group of small traders who have high confidence and high control, with a small value of portfolio.
\end{abstract}

Keywords: classification, investor profile, irrational, confident big trader, loss averse small trader.

\begin{abstract}
ABSTRAK
Penelitian ini bertujuan untuk melakukan klasifikasi terhadap tipe investor individu di pasar modal Indonesia. Tujuan klasifikasi tersebut adalah, selain memberikan gambaran bagi perusahaan sekuritas tentang profil investor individu di pasar modal Indonesia, juga akan memberikan pengertian bagi investor individu tentang kebiasaan investasi mereka, sehingga bisa mendorong kebiasaan trading yang baik dan membuat investor memperoleh kinerja yang baik dari hasil investasi mereka. Dari profil investor tersebut, peneliti membuat petunjuk praktis yang memasukkan unsur Behavioral Finance ke dalam design alokasi aset yang sesuai dengan profil investor secara pribadi, sehingga lebih bermanfaat bagi kepentingan investor tersebut. Hasil penelitian ini menunjukkan bahwa investor individu di Indonesia cenderung bersifat irasional dalam berinvestasi, dimana mereka bisa digolongkan dalam dua kelompok besar. Kelompok pertama adalah kelompok confident big trader yang memiliki rasa percaya diri serta kontrol yang tinggi, serta nilai portfolio besar. Kelompok kedua adalah kelompok loss averse small trader yang memiliki rasa percaya diri serta kontrol yang tinggi, dengan nilai portfolio yang kecil.
\end{abstract}

Kata kunci : klasifikasi, profil investor, irasional, confident big trader, loss averse small trader.

\section{PENDAHULUAN}

Perkembangan pasar modal Indonesia selama beberapa tahun ini sangat pesat, dimana Indeks Harga Saham Gabungan (IHSG) selama 8 tahun dari tahun 2004-2012 mencatat kenaikan secara akumulatif sebesar $452 \%$ atau rata-rata mencapai kenaikan $57 \%$ per tahun. Sebuah laju kenaikan yang luar biasa bila dibandingkan dengan negara lain seperti Cina, India dan lain-lain.

Selama tahun 2004-2012 terdapat paling tidak 141 perusahaan yang melakukan penawaran umum atau Initial Public Offering (IPO) di Bursa Efek Indonesia(BEI), ini menunjukkan bahwa tingginya minat emiten untuk masuk ke pasar modal Indonesia 
sebagai sumber pendanaan perusahaan (Indonesia Economic Review, 2004-2012). Hal ini bisa terjadi karena pasar modal Indonesia menarik baik bagi perusahaan yang membutuhkan pendanaan maupun investor yang memiliki kelebihan dana untuk berinvestasi.

Menurut data BEI, terdapat $365.651 \mathrm{sub}$ rekening investor domestik di bursa Indonesia pada akhir tahun 2011 (Komite Ekonomi Nasional, 2013). Namun dengan adanya perkembangan teknologi dan ilmu pengetahuan tentang investasi, diharapkan akan meningkatkan jumlah investor domestik di pasar modal Indonesia.

Berbagai kebijakan yang ditempuh oleh BEI untuk meningkatkan investor domestik, terutama investor pribadi dalam pasar modal Indonesia, antara lain kebijakan single $I D$, untuk menghindari kemungkinan manipulasi oleh perusahaan sekuritas, sehingga investor pribadi akan terjamin keamanan nilai portfolionya.

Dengan semakin meningkatnya jumlah investor pribadi, maka semakin penting bagi kita untuk memahami motivasi, pemikiran dan gaya pengambilan keputusan investasi dari investor pribadi. Penelitian terdahulu meneliti tentang gaya investasi broker saham (Morrin et al. dalam Johnson et all, 2005) atau segmentasi investor saat memilih perusahaan sekuritas (Chan et al., dalam Wood dan Zaichkowsky, 2004). Pe nelitian tersebut menunjukkan bahwa membuat profil bagi investor individu tentang penggunaan informasi pasar dan sejarah investasi mereka akan membantu perusahaan sekuritas untuk lebih selektif dalam melakukan promosi dan komunikasi terhadap investor individu tersebut (Wood dan Zaichkowsky, 2004).

Hal tersebut yang menjadi dasar bagi penulis untuk melakukan klasifikasi terhadap tipe investor individu di pasar modal Indonesia. Penulis ingin mengetahui bagaimana profil investor di pasar modal Indonesia. Apakah mereka tergolong investor yang overconfidence atau mereka tergolong investor yang rasional. Bagaimana sikap mereka terhadap risiko dan ketidakpastian, bagaimana penggunaan informasi oleh investor dan sejarah transaksi investor individu. Tujuan klasifikasi tersebut selain memberikan gambaran bagi perusahaan sekuritas tentang profile investor individu di pasar modal Indonesia, klasifikasi ini juga akan memberikan pengertian bagi investor individu tentang kebiasaan investasi me reka, sehingga bisa mendorong kebiasaan trading yang baik dan membuat investor memperoleh kinerja yang baik dari hasil investasi mereka.

\section{TINJAUAN TEORETIS}

Saat pengambilan keputusan mengenai suatu investasi, investor dihadapkan pada suatu kondisi untuk menentukan pilihan investasi mana yang dapat memberikan return sesuai yang diinginkan investor. Penentuan pilihan investasi oleh investor dipengaruhi oleh cara investor melakukan proses atas informasi yang dimilikinya.

Dalam teori investasi disebutkan bahwa investor diasumsikan rasional dan memperhitungkan return dan risk dalam proses pengambilan keputusan investasi. Hal ini sesuai dengan teori yang dikemukakan oleh Markowitz (dalam Acharya dan Pedersen, 2005), yang menjelaskan bahwa investor cenderung akan memilih investasi yang paling menguntungkan bagi investor dan berusaha untuk meminimalkan risiko dengan cara diversifikasi.

Selanjutnya, teori tersebut dikembangkan oleh Treynor; Sharpe; Lintner dan Mossin(dalam Acharya dan Pedersen, 2005) yang dikenal dengan teori Capital Asset Pricing Model (CAPM). Teori ini memprediksi expected rates of return dan risk dari investasi atas aset yang berisiko. Salah satu asumsi yang mendasari teori ini adalah bahwa investor bersifat rasional dan memiliki ekspektasi yang homogen, atau cara berpikir yang homogen dalam menganalisis informasi. Selain itu, teori CAPM percaya bahwa pasar saham itu bersifat efisien (Efficient Market Hypothesis / EMH). 
Implikasi dari EMH adalah bahwa harga sekuritas telah mencerminkan semua informasi yang tersedia bagi investor di pasar dan harga sekuritas di pasar sudah "fair", sehingga tidak ada abnormal return bagi investor. Pada kenyataan adanya anomali-anomali yang terjadi di pasar modal dimana ada abnormal return bagi beberapa investor. Hal ini membuktikan bahwa harga sekuritas di pasar tidak "fair". Oleh sebab itu, muncul teori lain yang membantah supremasi teori CAPM yaitu Behavioral Finance yang dikemukakan oleh Shleifer dan Summers (dalam Shiller, 2003). Teori ini menyatakan bahwa investor itu mungkin tidak rasional, dan juga memiliki proses pengolahan informasi yang berbedabeda antar orang, hal ini menyebabkan kemungkinan investor mengambil keputusan investasi yang salah, atau hanya berdasarkan "feeling" saja. Akibat dari ketidakrasionalan investor, maka investor bisa mengambil keputusan yang salah, bahkan cenderung emosional. Hal ini menunjukkan adanya faktor psikologi yang mempengaruhi proses pengambilan keputusan dalam investasi.

\section{Capital Asset Pricing Model (CAPM)}

Capital Asset Pricing Model (CAPM) dikembangkan oleh Treynor; Sharpe; Lintner dan Mossin (dalam Acharya dan Pedersen, 2005). Teori ini memprediksi hubungan antara risk dan expected return dari aset yang berisiko. Penerapan dari teori CAPM pada investor didasarkan pada beberapa asumsi, yaitu:investor tidak dapat mempengaruhi harga berdasarkan transaksi individu. Dengan demikian pasar modal digolongkan sebagai pasar persaingan sempurna, dimana: semua investor merencanakan jangka waktu investasi yang sama; investor membentuk portofolio dari financial asset yang diperdagangkan dan memiliki akses untuk meminjam (borrowing) dan meminjamkan (lending); tidak ada pajak atau biaya transaksi; semua investor mencoba untuk membentuk efficient frontier portfolio, dengan demikian investor tersebut adalah investor yang rasional; semua investor menganalisis surat berharga dengan cara yang sama dan mempunyai pandangan ekonomi yang sama juga. Ini berarti investor menggunakan expected return, standar deviasi dan korelasi yang sama untuk membentuk efficient frontier dan optimal risky portfolio. Asumsi ini disebut homogeneous expectations.

Dari teori CAPM, bisa terlihat indikator seorang investor dinyatakan rasional adalah sebagai berikut: a) investor akan memperhitungkan semua kemungkinan investasi sebelum dia memutuskan pembelian investasi tertentu; b) hasil keputusan yang sudah diambil oleh investor tidak akan disesalkan oleh investor tersebut di kemudian hari.

Investor akan mengambil keuntungan yang setinggi-tingginya dan apabila terjadi kerugian, investor yang rasional akan melakukan cut loss, sehingga nilai kerugiannya minimal. Investor menurut teori CAPM adalah tipe investor yang rasional, mereka tidak akan memiliki penyesalan setelah pengambilan keputusan, tidak ada masalah salah pilih instrumen, dan lain-lain.

\section{Pengambilan Keputusan}

Ketika individu maupun organisasi membuat keputusan, pada dasarnya terdapat tiga model, yaitu rational decisionmaking, bounded rationality, dan intuition (Robbins dan Judge, 2013). Rational decisionmaking model adalah model pengambilan keputusan yang mendeskripsikan bagaimana individu seharusnya berperilaku agar dapat memaksimalkan outcome. Asumsi yang digunakan adalah bahwa pembuat keputusan memiliki informasi yang lengkap, mampu mengidentifikasi semua opsi yang relevan tanpa bias, dan memilih opsi yang memberikan utilitas tertinggi. Model pengambilan keputusan yang rational mengikuti tahap-tahap sebagai berikut: 1) mendefinisikan masalah; 2) mengidentifikasikan kriteria keputusan; 3) mengalokasikan bobot untuk tiap kriteria; 4) mengembangkan alternatif-alternatif; 5) mengevaluasi tiap 
alternatif; dan 6) memilih alternatif yang terbaik.

Bounded rationality merupakan proses pengambilan keputusan dimana kemampuan individu untuk memproses informasi adalah terbatas, sehingga hampir tidak mungkin untuk mendapatkan dan memahami semua informasi yang dibutuhkan untuk mengoptimalkan outcome. Disini individu berusaha untuk mendapatkan solusi yang paling mencukupi dan memuaskan, sedangkan intuition merupakan model pengambilan keputusan yang paling tidak rasional, yaitu merupakan proses di bawah sadar yang diciptakan dari hasil menyaring pengalaman. Ini terjadi di luar pemikiran sadar, bergantung pada asosiasi holistik, atau kaitan antara potongan-potongan informasi yang terpisah. Intuition tidak bersifat rasional, namun inipun tidaklah salah. Intuition dan rational dapat saling melengkapi satu sama lain.

Menurut Jensen dan Meckling (dalam Ghoshal, 2005), sifat manusia yang paling umum adalah model REMM (Resourceful, Evaluative, Maximizing Model). Mereka memiliki kesimpulan bahwa manusia itu kreatif dalam menilai kesempatan dalam kehidupan, mereka akan meresponi lingkungan dengan menciptakan kesempatan baru; manusia itu bersifat evaluatif, karena keinginan yang tak terbatas, maka manusia akan mengevaluasi segala pilihan yang tersedia, dan bersedia untuk melakukan tradeoff untuk menukarkan apa yang mereka miliki dengan hal yang lebih baik; terakhir manusia juga bersifat maximalisasi, dimana manusia akan selalu memaksimalkan kenikmatan yang mereka peroleh. Sifat-sifat ini cenderung diperlihatkan oleh manusia yang rasional dalam pengambilan keputusan di kehidupan

\section{Behavioral Finance}

Barberis dan Thaler (2003); Shefrin (dalam Johnson etal, 2005); Shiller (2005); dan Subrahmanyam (2008) menjelaskan Behavioral Finance sebagai sebuah model pasar keuangan yang menekankan impli- kasi potensial dari faktor psikologis yang mempengaruhi perilaku investor. Premisnya adalah bahwa teori keuangan konvensional kurang memperhatikan bagaimana orang sebenarnya membuat keputusan dan bahwa setiap orang membuat perbedaan. Semakin banyak ekonom menginterpretasikan literatur bahwa anomali pasar konsisten dengan irasionalitas, yang sepertinya menjadi ciri-ciri bagi para individu yang mengambil keputusan yang rumit.

Bodie et al., (2008) menuliskan dua argumen dasar dari kritik behavioral, yaitu irasionalitas dan keterbatasan kegiatan arbitrase. Irasionalitas, terdiri dari dua kategori luas: 1) investor tidak selalu memproses informasi dengan benar, dan karenanya dapat melakukan kesalahan dalam menghitung distribusi probabilitas laba di masa depan; 2) meskipun memiliki distribusi probabilitas laba, investor sering membuat keputusan yang tidak konsisten dan optimal.

Keberadaan investor yang tidak rasional saja tidak akan cukup untuk membuat pasar menjadi tidak efisien. Jika irasionalitas mempengaruhi harga, arbitrator yang cerdik dapat mengambil keuntungan dengan mendorong harga kembali ke nilainya yang wajar. Ini merupakan argumen behavioral yang kedua, bahwa pada prakteknya kegiatan arbitrase semacam di atas adalah terbatas dan tidak cukup untuk memaksa harga kembali ke nilai intrinsiknya. Pelaku pasar pada umumnya akan setuju bahwa jika harga adalah benar (harga pasar sama dengan nilai intrinsic), maka tidak ada peluang yang mudah untuk memperoleh laba.

Kesalahan dalam pemrosesan informasi dapat mengakibatkan investor salah memperkirakan probabilitas yang sebenarnya dari kejadian ataupun tingkat pengembalian dimasa depan. Beberapa bias pemrosesan informasi ini telah dibahas, empat diantaranya yang paling sering ditemui adalah Forecasting errors, berdasarkan beberapa penelitian yang dilakukan Kahneman dan Tversky (Johnson et. al, 2005) serta Tversky dan Kahneman (Kahneman, 
2003) memberikan indikasi bahwa orang sering memberi bobot lebih pada pengalaman terbaru dibandingkan apa yang dipercayai sebelumnya ketika membuat prediksi (kadang disebut juga bias memori) dan cenderung membuat prediksi yang terlalu ekstrim tanpa mempertimbangkan ketidakpastian dalam informasi yang mereka miliki; overconfidence, orang cenderung melebih-lebihkan ketepatan dari kepercayaan atau prediksi, dan terlalu percaya atas kemampuan mereka. Penelitian mengenai overconfidence dilakukan oleh Barber dan Odean (Wood dan Zaichkowsky, 2004) yang membandingkan kegiatan trading dan ratarata return dari akun broker pria dan wanita. Peneliti menyimpulkan pria lebih aktif bertransaksi $45 \%$ dibanding wanita. Hal ini sesuai dengan hasil penelitian psikologis yang menyatakan tingkat kepercayaan pria yang lebih tinggi dibanding wanita; conservatism, investor cenderung terlalu lambat atau konservatif dalam memperbaharui kepercayaan mereka sebagai respon atas penemuan baru. Misalnya jika investor kurang bereaksi terhadap berita fundamental, maka harga hanya mencerminkan informasi baru secara bertahap; sample size neglect and representativeness, orang cenderung tidak mementingkan ukuran sampel dengan alasan bahwa sampel yang kecil sama representatifnya dengan sampel yang besar. Oleh karenanya, beberapa pola harga mungkin terlalu cepat diinterpretasikan dan tren mungkin diekstrapolasikan terlalu jauh kedepan; confirmation bias, merupakan kecenderungan mencari penjelasan untuk menyakinkan diri sendiri. Misalnya kalau terjadi kerugian, itu hanya nasib buruk saja; availability bias, merupakan kecenderungan dramatisir masalah.

\section{Bias Psikologis}

Meskipun jika pemrosesan informasi dilakukan dengan benar, banyak studi menyimpulkan bahwa individu cenderung membuat keputusan yang tidak sepenuhnya rasional dengan menggunakan informasi tersebut. Bias-bias psikologis tersebut diantaranya (Bodie et al., 2008): framing, pengambilan keputusan dipengaruhi oleh bagaimana pilihan dikotak-kotak. Misalnya, individu dapat bertindak risk averse dalam konteks keuntungan tetapi bertindak sebagai risk seeking dalam konteks kerugian. Dalam banyak kasus, pilihan mengenai pengotakan dari pencarian resiko melibatkan keuntungan atau kerugian dapat dibolak-balik tergantung keadaan; mental accountting, merupakan suatu jenis pengotakan dimana orang memisahkan keputusan tertentu. Statman (Cheng, 2007; Bollen, 2007) membuat argumen bahwa mental accounting adalah konsisten dengan investor yang irasional yang lebih menyukai deviden tinggi dan cenderung merugi untuk jangka panjang; regret avoidance, individu yang membuat keputusan yang kemudian berdampak buruk akan memiliki penyesalan lebih apabila keputusan tersebut adalah atas sesuatu yang kurang konvensional.

Menurut Robbins dan Judge (2013) beberapa bias dan kesalahan yang sering terjadi dalam pengambilan keputusan adalah sebagai berikut: 1) overconfidence bias, terlalu optimis tanpa didukung fakta yang tepat; 2) anchoring bias, kecenderungan untuk memperbaiki informasi awal, dimana kemudian seseorang gagal untuk menyesuaikan informasi selanjutnya berdasarkan informasi awal tersebut; 3) confirmation bias, kecenderungan untuk mencari informasi yang mendukung pilihannya dimasa lalu dan memotong informasi yang kontradiksi dengan pertimbangannya di masa lalu; 4) availability bias, kecenderungan untuk mendasari pertimbangan pada informasi yang telah tersedia atau dimiliki; 5) escalation of commitment, berusaha meningkatkan komitmen pada keputusan sebelumnya dengan mengabaikan informasi negatif mengenai hal tersebut; 6) randomness error, kecenderungan individu untuk percaya bahwa mereka dapat memprediksi hasil dari kejadian yang supernatural; 7) risk aversion, kecenderungan untuk lebih memilih hasil yang pasti dengan jumlah yang moderat dibandingkan hasil yang lebih berisiko, 
walaupun hasil dari yang lebih berisiko tersebut jauh lebih besar; 8) hindsight bias, kecenderungan untuk yakin namun salah, dimana setelah suatu hasil dari kejadian diketahui, seseorang berperilaku seolaholah dapat memprediksi hasil dari kejadian dengan akurat.

Investor individu menurut Behavioral Finance belum tentu rasional, tapi mereka adalah orang normal. Orang normal yang bisa mengalami penyesalan setelah pengambilan keputusan, mengalami kesalahan kognitif dalam pemilihan instrumen, dan lain-lain. Masing-masing individu memiliki persepsi yang berbeda terhadap suatu masalah, sehingga dapat menghasilkan bias yang berbeda pula.

Menurut Pompian dan Longo (2005), bias perilaku individu ini dapat dibagi menjadi dua bagian yaitu bias emosional dan kognitif. Bias kognitif bersumber dari pengambilan keputusan yang salah (bounded rationality), sehingga bisa diperbaiki dengan informasi dan nasihat yang tepat, sedangkan bias emosional bersumber dari intuisi atau perasaan impulsif (intuition), sehingga sulit untuk diperbaiki. Bias kognitif contohnya bias anchoring, adjustment, availability dan bias representative, memori selektif dan overconfidence. Sedangkan bias emosional mencakup regret avoidance, risk aversion, hindsight dan denial.

Bagi investor individu, perusahaan sekuritas sebaiknya memiliki model kuantitatif dan petunjuk praktis dalam membantu mereka untuk membuat alokasi aset dalam portfolio yang optimal untuk meningkatkan kesejahteraan jangka panjang investor tersebut. Seperti yang dibuat oleh Pompian dan Longo (2005) dalam model adaptasi dan moderat untuk menciptakan suatu model portfolio yang sesuai dengan bias-bias psikologi individu. Model yang dikembangkan Pompian dan Longo (2005) sebagai berikut:

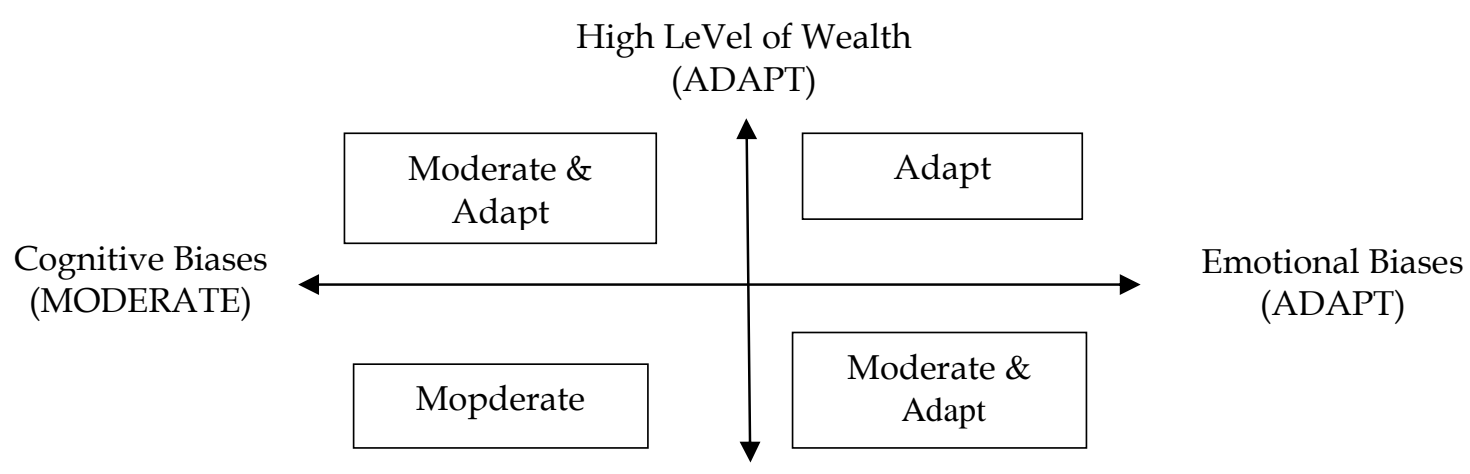

Low Level of Wealth (MODERATE)

Gambar 1

Model Moderate dan Adaptasi (Pompian dan Longo, 2005).

Praktisi seharusnya beradaptasi terhadap bias psikologi dari kelompok investor dengan kekayaan tinggi dan mencoba untuk memodifikasi perilaku kelompok investor dengan kekayaan rendah. Praktisi seharusnya beradaptasi terhadap bias emosional dan bias kognitif moderat. Tindakan ini akan menghasilkan praktek alokasi porfolio terbaik.
Hasil penelitian Pompian dan Longo (2005) merupakan lanjutan dari penelitian mereka tahun 2004 (Pompian dan Longo, 2004) yang berhasil menemukan aplikasi praktis bagi praktisi keuangan untuk menyesuaikan alokasi aset dalam portfolio dengan gender dan toleransi terhadap risiko yang berbeda dari masing-masing investor individu. 
Hasil penelitian mereka ini sejalan dengan hasil penelitian Lo (2005) mengenai Hipotesis Pasar Adaptif (The Adaptive Market Hypothesis), yaitu bahwa tingkat efisiensi pasar tergantung pada faktor lingkungan seperti jumlah persaingan di pasar, kesempatan profit yang ada dan adaptasi individu-individu di pasar (bias-bias psikologi individu).

Penelitian untuk mengombinasikan teori efisiensi pasar dengan teori Behavioral Finance juga dilakukan oleh Chhabra (2005). Chhabra mencoba membuat skema alokasi aset dan risiko investor yang menyesuaikan profil risiko dan kemampuan investor.

\section{Tahap Perkembangan Karir}

Teori Behavioral Finance juga dikaitkan dengan fase psikologis dari manusia antara lain bisa dilihat dari tahap perkembangan karir. Menurut Greenhaus (Werner dan DeSimone, 2009), terdapat 5 (lima) tahap Pengembangan Karir. Tahap 1. Occupational Choice: Preparation for Work, berada di kisaran usia 0-25 tahun. Pada tahap ini tugas utamanya adalah mengembangkan occupational self-image, menilai pekerjaanpekerjaan alternatif, mengembangkan pilihan pekerjaan awal, dan mengejar pendidikan yang diperlukan; Tahap 2. Organizational Entry, berada pada kisaran usia 18-25 tahun. Tugas-tugas utama pada tahap ini adalah meraih pekerjaan yang ditawarkan dari organisasi yang diingini, dan memilih pekerjaan yang tepat berdasarkan informasi yang akurat; Tahap 3. Early Career: Establishment and Achievement, berada rentang usia 25-40 tahun. Pada usia ini individu mempelajari pekerjaan, mempelajari aturan dan norma organisasi, memilih pekerjaan, karir dan organisasi yang dirasa paling cocok, meningkatkan kompetensi, serta mengejar impian-impiannya; Tahap 4. Midcareer, berada pada rentang usia 40-55 tahun. Tahap ini juga merupakan midlife transition. Pada tahap ini individu menilai kembali karir awalnya dan masa dewasa awalnya, serta memastikan kembali atau memodifikasi mimpinya, membuat pilihan yang tepat di masa middle adult years, serta tetap produktif dalam bekerja. Di tahap ini sering juga terjadi mid-career crisis. Krisis ini bisa berbeda dampaknya bagi individu yang satu dan lainnya, misalnya menghadapi kenyataan karirnya datar-datar saja dan merasa keterampilan yang dimiliki saat ini tidak lagi cukup untuk dapat menyelesaikan tugas yang dibebankan kepadanya, terutama karena perubahan teknologi. Individu yang sukses menghadapi tahap ini akan tetap produktif, namun yang tidak berhasil mengatasinya akan mengalami stagnasi dan frustrasi; Tahap 5. Late Career, berada pada rentang usia 55 tahun hingga pensiun. Pada tahap ini seseorang tetap produktif dalam kerja, mempertahankan self-esteem, serta bersiap-siap untuk pensiun secara efektif.

Menurut London dan Mone (Werner dan DeSimone, 2009), terdapat 3 aspek motivasi karir, yaitu: 1. Career Resilience, derajat dimana seseorang berjuang melawan hambatan karir yang mempengaruhi pekerjaannya, termasuk di dalamnya adalah rasa percaya diri, kebutuhan untuk berprestasi, kemauan mengambil risiko, dan kemampuan untuk bertindak secara independen dan kooperatif; 2. Career Insight, derajat dimana individu mulai secara realistis menilai dirinya dan karirnya, dan bagaimana persepsi ini dikaitkan dengan tujuan karirnya. Termasuk di dalamnya adalah pengembangan tujuan karir dan meningkatkan pengetahuan bagi dirinya dan lingkungannya; 3. Career Identity, derajat dimana individu mendefinisikan dirinya dengan pekerjaannya, termasuk pula keterlibatan dalam pekerjaan, organisasi, profesi, dan arah karirnya.

Menurut Bohlander dan Snell (2013), terdapat 5 tahap perkembangan karir. Tahapannya adalah sebagai berikut: tahap 1) preparation for work (usia 0-25 tahun), yang dicirikan membangun self-image dalam pekerjaan, menilai berbagai alternatif pekerjaan, mengembangkan pilihan pekerjaan awal, mengejar pendidikan yang diperlukan; tahap 2) organizational entry (usia 18-25 tahun), yang dicirikan menerima pekerjaan 
yang ditawarkan dari organisasi yang diinginkan, memilik pekerjaan berdasarkan informasi yang lengkap dan akurat; tahap 3) early career (usia 25-40 tahun), yang dicirikan mempelajari pekerjaan, mempelajari aturan dan norma organisasi, merasa cocok dengan organisasi dan pekerjaan yang dipilih, meningkatkan kompetensi, dan mengejar tujuan yang diharapkan; tahap 4) midcareer (usia 40-55 tahun), yang dicirikan menilai kembali karir mula-mula dan tujuan awal, memastikan ataupun memodifikasi tujuan, membuat pilihan yang tepat dengan masa middle adult, serta tetap produktif; tahap 5) late career (usia 55 hingga pensiun), yang dicirikan tetap produktif dalam bekerja, mempertahankan self-esteem, dan mempersiapkan pensiun yang efektif.

Menurut Noe (2010), model dari perkembangan karir seseorang adalah sebagai berikut:

Tabel 1

Career Development Model

\begin{tabular}{|c|c|c|c|c|}
\hline & & & reer Stage & \\
\hline & Exploration & Establishment & Maintenance & Disengagement \\
\hline $\begin{array}{l}\text { Developmental } \\
\text { tasks }\end{array}$ & $\begin{array}{l}\text { Identify interests, } \\
\text { skills, fit between } \\
\text { self and work }\end{array}$ & $\begin{array}{l}\text { Advancement, } \\
\text { growth, security, } \\
\text { develop lifestyle }\end{array}$ & $\begin{array}{l}\text { Hold on to } \\
\text { accomplishments, } \\
\text { update skills }\end{array}$ & $\begin{array}{l}\text { Retirement } \\
\text { planning, change } \\
\text { balance between } \\
\text { work and nonwork }\end{array}$ \\
\hline Activities & $\begin{array}{l}\text { Helping, learning, } \\
\text { following direction }\end{array}$ & $\begin{array}{l}\text { Making } \\
\text { independent } \\
\text { contributions }\end{array}$ & $\begin{array}{l}\text { Training, } \\
\text { sponsoring, } \\
\text { making }\end{array}$ & $\begin{array}{l}\text { Phasing oout of } \\
\text { work }\end{array}$ \\
\hline $\begin{array}{l}\text { Relationship to } \\
\text { other employees }\end{array}$ & Apprentice & Colleague & Mentor & Sponsor \\
\hline Typical age & Less than 30 & $30-45$ & $45-60$ & $61+$ \\
\hline Years on job & Less than 2 years & $2-10$ years & More than 10 years & $\begin{array}{l}\text { More than } \\
\text { years }\end{array}$ \\
\hline
\end{tabular}

Sumber: Noe, 2010

Berdasarkan model di atas dapat di ketahui bahwa terdapat 4 tahap perkembangan karir, yaitu tahap exploration, establishment, maintenance, dan disengagement. Di- mana dalam tiap-tiap tahapnya memiliki karakteristik masing-masing, sedangkan menurut Mathis dan Jackson (2003), periode perkembangan karir adalah sebagai berikut:

Tabel 2

General Career Periods

\begin{tabular}{lllll}
\hline \hline Career stage & Early Career & \multicolumn{1}{c}{ Mid-Career } & Late Career & \multicolumn{1}{c}{ Carrer End } \\
\hline Age group: & \multicolumn{2}{c}{$\mathbf{2 0}$ years } & \multicolumn{3}{c}{$\mathbf{3 0 - 4 0}$ years } & 50 years & \multicolumn{6}{c}{$\mathbf{6 0 - 7 0}$ years } \\
\hline Needs: & Identifying & Advancing in career; & Updating skills; & Planning for \\
& interests, & lifstyle may limit & settled in, & retirement, \\
& exploring & options, growth, & leader, opinions & examining \\
& several jobs. & contribution. & valued. & nonwork interests. \\
Concerns: & External & Values, contribution, Mentoring, & Retirement, part- \\
& rewards, & integrity, well-being. & disengaging, & time employment. \\
& acquiring more & & organization & \\
& capabilities. & & continuance. & \\
\hline
\end{tabular}

Sumber: Mathis and Jackson, 2003 
Menurut Mayo, yang dikutip oleh Dwikusumastuti (2008), perjalanan karir terbagi dalam tiga tahapan, yaitu: discovery phase, consolidation phase, dan maturity phase. Jika mampu melewati ketiga fase ini dengan baik, maka keberhasilan akan didapatkan. Jika tidak, kegagalanlah yang akan dirasakan. Tiga tahapan dalam perjalanan karir: 1) discovery phase; Fase ini dialami orang berusia 20 tahunan. Berlangsung sekitar sepuluh tahun pertama dalam dunia kerja. Di tahap ini, seseorang adalah angkatan kerja baru karena kemungkinan besar seseorang tersebut baru lulus dari bangku perguruan tinggi, seseorang sedang giat-giatnya mencari dan mengejar pekerjaan impian. Sebagai orang yang baru terjun ke dunia kerja, orang tersebut akan belajar beradaptasi dengan dunia baru tersebut. Seseorang akan belajar tentang dunia kerja dari berbagai pihak. Di tahap ini, seseorang berupaya mengenali kemampuan diri. Dan, ketika fase "pencarian jati diri" ini sudah dilalui, seseorang akan mulai menentukan arah dan masa depan karir. Dampaknya, sebagai "orang baru" mereka memiliki semangat menggebu-gebu, harapan besar, dan citacita tinggi. Namun, mereka akan menjumpai berbagai kendala, terutama berkaitan dengan adaptasi lingkungan kerja. Bagi seseorang yang baru lulus akan sering mengalami konfllik, karena apa yang diperoleh di bangku sekolah atau kuliah berbeda dengan kenyataan di lapangan. Situasi ini akan mempengaruhi pilihan karier seseorang dalam memilih bidang yang sesuai dengan minat, keinginan, dan bahkan idealisme; 2) consolidation phase; fase ini biasanya berlangsung pada usia 30-40 tahunan. Ada yang memulai fase ini lebih awal dan ada pula yang terlambat. Demikian pula dengan akhir fase ini, ada yang mengakhirinya lebih awal, dan ada pula yang terlambat. Di tahap ini seseorang mulai bersikap realistis, orientasi karir mulai terarah. Kesadaran bahwa jenjang karir harus dijalani untuk meraih sebuah tujuan, mendorong seseorang untuk membayangkan sebuah jalur karir yang harus dilalui untuk mencapai tujuan. Di fase ini juga, perjalanan karir akan sampai pada tahap pematangan yang bertumpu pada pengalaman sebagai andalan dalam pengembangan diri. Pengalaman dalam bidang tertentu ini yang layak untuk 'dijual' sebagai kompetensi diri. Dampaknya, seseorang akan menghadapi pilihanpilihan karir, mau jalan terus atau 'belok' ke arah lain. Untuk itu, seseorang harus melakukan evaluasi ulang mengenai pilihan karir di tahap awal, apa harus terus berada pada track yang telah dijalani, atau pindah jalur untuk memenuhi cita-cita yang diinginkan; 3) maturity phase; inilah fase terakhir dari sebuah perjalanan karir. Fase ini banyak diisi oleh mereka yang memasuki usia 50 tahunan ke atas, yang terjadi bagi sebagian orang fase ini adalah persiapan memasuki masa pensiun tanpa harus kehilangan produktivitas. Sementara bagi sebagian kecil diantaranya adalah persiapan menduduki posisi yang lebih tinggi seperti komisaris, konsultan, atau pemimpin organisasi. Dampaknya, mereka yang berhasil melewati fase pertama dan kedua dengan baik akan memiliki akumulasi pengetahuan dan pengalaman yang sangat banyak di fase ini. Ini akan sangat bermanfaat untuk tempat kerja mereka. Dan, bagi mereka yang dapat menduduki kepemimpinan senior, ini akan membuat mereka merasa masih berguna dan tidak terpinggirkan dalam lingkungan masyarakat. Sebaliknya, jika mereka gagal melewati fase pertama dan kedua, pada fase ini biasanya akan kehilangan fleksibilitas, gagal memahami nilai-nilai yang dinamis, tidak mampu mengikuti perubahan lingkungan, dan pastinya akan tertinggal.

\section{Hasil Penelitian Sebelumnya}

Perilaku investor yang irasional banyak diteliti oleh para ilmuwan. Antara lain Odean (Shiller, 2003); Dhar dan Zhu (2006); Frazzini (2006); Grinblatt dan Han (2005); serta Grinblatt dan Keloharju (2009) menemukan adanya efek disposisi (disposition effect) yaitu bahwa investor cenderung merealisasikan keuntungan terlalu cepat 
dan memotong kerugian terlalu lama, dengan cara menjual saham yang sedang mengalami kenaikan harga terlalu cepat, dan menahan saham yang mengalami penurunan harga terlalu lama. Hasil penelitian Dhar dan Zhu (2006) bahwa efek disposisi lebih kecil untuk investor individu profesional dan memiliki penghasilan lebih tinggi. Penelitian Barber et al., (2007, 2009) menemukan bahwa meskipun efek disposisi terdapat pada investor individu dan institusi, namun investor individu yang memiliki efek disposisi yang paling besar. Hasil penelitian Brown et al., (2006) menyatakan bahwa trader dengan nilai besar lebih kurang rentan terhadap efek disposisi. Calvet et al., $(2007,2009)$ juga menemukan bahwa individu yang kurang terpelajar lebih rentan terhadap efek disposisi. Penelitian Feng dan Seasholes (2005) menemukan bahwa pengalaman trading dan kompleksitas (sophistication) investor memperbaiki efek disposisi.

Ini sesuai dengan teori Prospek yaitu penjelasan analitis atas investor yang riskaverse. Orang akan cenderung mengambil risiko pada saat harga naik dan cenderung berhati-hati atau risk-averse pada saat harga bergerak turun. Investor menurut hasil penelitian Kahneman dan Tversky (Camerer et. al, 2004) cenderung loss-averse, artinya manusia cenderung sangat menghindari kerugian dan ingin memperoleh keuntungan. Hal yang sama juga diteliti oleh Barber dan Odean (2011); Grinblatt dan Han (2005); Hens dan Vlcek (2011); Kyle et al., (2006); Kaustia (2004, 2010a, 2010b); Muermann dan Volkman (2006); Summers dan Duxbury (2007); Strahilevitz et al. (2011); Yao dan Li (2013).

Barber dan Odean (Barberis dan Thaler, 2003) dan Odean (Barberis dan Thaler, 2003) juga menemukan bahwa individu yang terlalu sering trading adalah investor yang sering mengalami kerugian. Hasil ini sesuai juga dengan penelitian Barber et al., (2005) di bursa saham Taiwan serta penelitian Kaniel et al., (2008) di bursa saham New York. Penelitian Dorn dan Huberman (2005) menemukan bahwa investor yang lebih toleransi terhadap risiko cenderung sering bertransaksi, namun mereka yang mengganggap diri lebih pintar akan bertransaksi lebih agresif. Hal ini juga ditemukan oleh Glaser dan Weber (2007) dan Graham et al., (2009). Anderson (2008) menemukan bahwa investor dengan pendapatan rendah, lebih miskin, lebih muda dan kurang berpendidikan akan lebih banyak berinvestasi dalam saham, bertransaksi lebih sering dan memiliki kinerja yang lebih buruk.

Barber dan Odean (Wood dan Zaichkowsky, 2004) juga memperoleh hasil bahwa investor yang trading secara online adalah investor yang agresif sebelum mereka online, tapi tidak memperoleh hasil yang baik setelah mereka transaksi online. Benartzi dan Thaler (2007) meneliti tentang perilaku investor yang irasional dimana investor hanya mengikuti aturan alokasi $1 / \mathrm{n}$ dalam memilih portfolio tanpa melihat keuntungan dari saham/obligasi. Hasil yang sama juga diperoleh Barberis dan Xiong (2009). Namun menurut penelitian Seru et al. (2010), investor bisa belajar untuk memperoleh hasil yang lebih baik melalui sering trading.

Kamstra et al.(2010) memperoleh hasil penelitian bahwa perpindahan waktu dari dan ke siang mempunyai pengaruh kuat terhadap return saham. Bouman dan Jacobsen (Hong dan Yu, 2009) mendapatkan bahwa terdapat efek musim yang kuat dimana pasar cenderung naik pada saat musim dingin dan cenderung turun saat musim panas.

Lakonishok et al. (Johnson et al., 2005) menemukan bahwa kinerja return dari glamour stock (saham dengan $\mathrm{P} / \mathrm{B}$ yang tinggi) tidak sebagus value stock. Masih terdapat berbagai literatur yang membuktikan bahwa investor tidak berlaku rasional saat mengambil keputusan tentang investasi. Diantaranya Griffin dan Tversky (Wood dan Zaichkowsky, 2004), Barberis et al., (2005) yang menemukan bahwa investor cenderung bereaksi berlebihan terhadap isu-isu pasar dan tidak memperhatikan 
saham secara individu. Barber dan Odean (2009) juga menemukan bahwa investor cenderung membeli saham yang sedang menjadi pusat perhatian pasar (attention buying behavior), tanpa menilai saham itu secara mendalam. Hasil ini sejalan dengan penelitian Seasholes dan Zhu (2010), yang menyatakan bahwa transaksi investor individu tidak menambah nilai bagi saham, hal ini juga diteliti oleh Seasholes dan Wu (2007).

Teori CAPM menyatakan bahwa investor tidak bisa memprediksi return saham masa depan dengan menggunakan data historis. Namun hasil penelitian Haugen dan Baker (Barberis dan shleifer, 2003) menunjukkan bahwa rata-rata return saham selama 1 bulan, 2 bulan dan 12 bulan serta volume trading dibandingkan kapitalisasi pasar merupakan prediktor return saham yang ampuh dibandingkan dengan rumus CAPM (beta) dan total volatilitas.

Overconfidence investor menurut Barber dan Odean (Barberis dan Thaler, 2003) serta Griffin dan Tversky (Wood dan Zaichkowsky, 2004) dimanifestasikan dalam berbagai bias psikologis antara lain ilusi pengetahuan, hindsight bias, self attribution bias dan ilusi kontrol. Ilusi pengetahuan (illusion of knowledge) terjadi saat orang diberikan informasi yang banyak yang menjadi dasar forecast (proyeksi). Seperti yang dijelaskan oleh hasil penelitian Oskamp (Wood dan Zaichkowsky, 2004) bahwa ketepatan proyeksi cenderung meningkat lebih lambat daripada keyakinan investor. Jadi investor bisa saja percaya bahwa data terutama data internet mengandung pengetahuan dan mereka terlalu mengandal kan diri pada data tersebut. Investor yang menghabiskan uang dan waktu yang banyak untuk mengumpulkan informasi akan yakin bahwa informasi yang dikumpulkan itu berguna, ini menyebabkan adanya ketidaksesuaian kognitif (cognitive dissonance) (Barber dan Odean dalam Wood dan Zaichkowsky, 2004; Korniotis dan Kumar, 2009; Peng dan Xiong, 2006; Scheinkman dan Xiong, 2003). Hindsight bias adalah bias psikologi bila investor percaya bahwa mereka bisa memprediksi kejadian ekonomi berdasarkan apa yang sudah terjadi di masa lampau. Penelitian Kaustia dan Knupfer (2008) membuktikan adanya bias ini. Penelitian Coval et al., (2005) juga menemukan bahwa investor dengan kinerja yang baik di masa lalu cenderung akan membeli saham dengan return tinggi seminggu setelah pembelian. Penelitian Døskeland dan Hvide (2011) memiliki hasil bahwa investor lebih banyak membeli saham industri dimana dia bekerja, kendati menghasilkan return negatif. Penelitian Huang (2010) juga membuktikan bias ini.

Self attribution bias terjadi ketika investor cenderung mengatribusikan kesuksesan mereka dengan kemampuan pribadi mereka dan kegagalan mereka dengan nasib buruk atau tindakan orang lain. Individu juga cenderung mengabaikan, atau tidak mempertimbangkan informasi yang menurunkan rasa percaya diri mereka, sehingga mereka cenderung melupakan kegagalan masa lalu (Daniel dan Titman, dalam Wood dan Zaichkowsky, 2004). Investor dengan bias over confidence juga diteliti oleh Moore dan Healy (2008). Langer dan Roth (Wood dan Zaichkowsky, 2004) menemukan bahwa individu bertindak seolah-olah keterlibatan langsung mereka bisa mempengaruhi hasil dari suatu kejadian. Ini khususnya berlaku bagi investor yang trading online. Investor ini merasa mereka memiliki kuasa (kontrol) untuk merubah sesuatu (Balasubramanian et al., 2003). Overconfidence membuat investor menjadi terlalu yakin akan pendapat mereka, sehingga tidak mempertimbangkan pendapat orang lain. Mereka memiliki expected return yang kecil karena terlalu sering bertransaksi. Mereka cenderung menghabiskan uang terlalu banyak untuk mengumpulkan informasi. (Odean; Barber dan Odean, dalam Wood dan Zaichkowsky, 2004).

\section{Pengembangan Hipotesis}

Hipotesis konseptual dalam penelitian ini adalah: Profil investor individu Indonesia dalam melakukan keputusan investasi 
lebih banyak dipengaruhi oleh alasan irasional. Peneliti ingin mengetahui model alokasi aset dalam portfolio yang sesuai dengan profil investor Indonesia yang bersifat irasional.

\section{METODE PENELITIAN}

Penelitian ini menggunakan data primer dengan menggunakan kuesioner. Sampel penelitian sebanyak 250 orang. Pengambilan sampel dengan metode convenience sampling. Kuesioner yang dikumpulkan yang dinilai valid dan lengkap sebanyak 200 buah. Kriteria pemilihan sampel adalah investor individu di pasar modal modal yang sudah aktif melakukan transaksi minimal 1 bulan. Peneliti terlebih dahulu melakukan pretest terhadap 30 orang responden.

Untuk mengidentifikasi profil investor individu, maka peneliti akan menggunakan kuesioner yang berisi pertanyaan-pertanyaan kualitatif. Kuesioner ini mengikuti model penelitian yang dilakukan oleh Wood dan Zaichkowsky (2004). Kuesioner ini meliputi 5 karakteristik mengenai profil investor yaitu: 1) horizon investasi jangka panjang/ pendek; 2) sikap terhadap risiko; 3) personalisasi atas kerugian; 4) percaya diri; dan 5) kontrol. Masing-masing pertanyaan tentang profil investor menggunakan skala Likert dari skala 1 sampai 7. Bagian kedua dari kuesioner adalah pertanyaan mengenai preferensi investor tentang bagaimana kebiasaan transaksi, penggunaan informasi dan portfolio saham yang dibeli serta dijual, proporsi investasi dan preferensi akan informasi.

\section{Definisi Operasional}

Definisi operasional investor rasional dan investor irasional dalam penelitian ini akan dijelaskan di bawah ini.
Investor rasional adalah investor yang memiliki ciri-ciri sebagai berikut: memperhitungkan semua kemungkinan investasi sebelum dia memutuskan pembelian investasi tertentu; horizon investasi jangka panjang; hasil keputusan yang sudah diambil oleh investor tidak akan disesalkan oleh investor tersebut di kemudian hari (tidak ada penyesalan); mengambil keuntungan yang setinggi-tingginya dan apabila terjadi kerugian, investor yang rasional akan melakukan cut loss, sehingga nilai kerugiannya minimal.

Investor irasional adalah investor yang memiliki ciri-ciri sebagai berikut: memiliki kepercayaan diri yang berlebihan (overconfidence); memiliki horizon investasi jangka pendek; memiliki regret avoidance; cenderung menyesali keputusan investasi yang sudah diambil terutama dalam keadaan laba; suka memiliki kontrol atas investasi yang diwujudkan dengan terlalu sering transaksi; dan tidak memperhitungkan semua kemungkinan investasi sebelum memutuskan pembelian investasi.

\section{Teknik Analisis Data}

Untuk uji realibilitas menggunakan me tode Cronbach's alpha dengan bantuan software SPSS 17, sedangkan untuk uji validitas menggunakan Korelasi Spearman. Selanjutnya untuk melakukan klasifikasi digunakan metode Cluster.

\section{ANALISIS DAN PEMBAHASAN Statistik Deskriptif}

Kuesioner disebarkan kepada 250 responden, namun yang valid hanya sejumlah 200 responden. Datanya adalah dapat dilihat pada tabel 3.

Data responden yang ditanyakan adalah jenis kelamin, usia, status pernikahan, pendidikan terakhir, pekerjaan, dan masa kerja. 
Tabel 3

Statistik Deskriptif

\begin{tabular}{lccccc}
\hline \hline & N & Minimum & Maximum & Mean & Std. Deviation \\
\hline Jenis kelamin & 200 & 1 & 2 & 1.35 & .477 \\
Usia & 200 & 2 & 5 & 3.23 & .387 \\
Status pernikahan & 200 & 1 & 2 & 1.40 & .197 \\
Pendidikan terakhir & 200 & 3 & 4 & 3.63 & .259 \\
Pekerjaan & 200 & 2 & 4 & 3.09 & .373 \\
Masa kerja & 200 & 2 & 6 & 3.07 & .728 \\
Valid N (listwise) & 200 & & & & \\
\hline
\end{tabular}

Sumber: Hasil data olahan

Berikut ini adalah statistik deskriptif dari kebiasaan trading responden.

Tabel 4

Statistik Deskriptif kebiasaan Trading

\begin{tabular}{lccccc}
\hline \hline & N & Minimum & Maximum & Mean & Std. Deviation \\
\hline Berapa lama investasi & 200 & 2 & 4 & 3.32 & .363 \\
Metode transaksi & 200 & 1 & 3 & 2.17 & .303 \\
Nilai portfolio & 200 & 3 & 6 & 4.43 & .654 \\
Jumlah transaksi & 200 & 2 & 4 & 3.25 & .439 \\
Sering perhatikan & 200 & 1 & 3 & 2.01 & .527 \\
Valid N (listwise) & 200 & & & & \\
\hline
\end{tabular}

Sumber: Hasil data olahan

Untuk mengetahui kebiasaan trading responden, kami menanyakan berapa lama investasi, metode transaksi, nilai portfolio, jumlah transaksi, dan sering perhatikan.

\section{Klasifikasi Cluster}

Untuk melakukan segmentasi profil investor, maka digunakan metode K-Mean cluster analysis.
Dari hasil iterasi, didapati dua cluster final. Dimana dari 6 karakteristik yang terkandung dalam kuesioner, hanya valid 3 buah karakteristik, yaitu horizon investasi jangka panjang/pendek, kontrol dan percaya diri. Dengan pertimbangan skala Likert 1-7 maka dibuat rentang skala untuk ketiga karakteristik tersebut.

Tabel 5

Rentang Skala Nilai Rata-Rata

\begin{tabular}{|c|c|c|c|}
\hline \multirow{2}{*}{ Kelas Interval } & \multicolumn{3}{|c|}{ Intepretasi } \\
\hline & Horizon investasi & Kontrol & Percaya Diri \\
\hline-1.8571 & $\mathrm{t}<1$ bulan & Sangat rendah & Sangat rendah \\
\hline $1.8572-2.7143$ & 1 bulan $\leq t<6$ bulan & rendah & rendah \\
\hline $2.7144-3.5715$ & 6 bulan $\leq \mathrm{t}<1$ tahun & Agak rendah & Agak rendah \\
\hline $3.5716-4.4287$ & $\mathrm{t}=1$ tahun & Sedang & Sedang \\
\hline $4.4288-5.2859$ & 1 tahun $<\mathrm{t}<3$ tahun & Agak tinggi & Agak tinggi \\
\hline $5.2860-6.1431$ & 3 tahun $\leq \mathrm{t}<5$ tahun & Tinggi & Tinggi \\
\hline $6.1432-7$ & $\mathrm{~T} \geq 5$ tahun & Sangat tinggi & Sangat tinggi \\
\hline
\end{tabular}

Ket : interval dibuat berdasarkan rumus rentang skala (Simamora, 2008) 
Untuk validasi hasil K-mean cluster dan untuk membedakan cluster berdasarkan ketiga unsur tersebut, maka dilakukan uji
Anova untuk membandingkan rata-rata tiap cluster. Berikut ini adalah tabel Anova dari kedua cluster.

Tabel 6

Anova dari Dua Cluster

\begin{tabular}{lcc}
\hline \hline & Cluster Mean Square & F-stat \\
\hline Horizon investasi jangka panjang/pendek & 2.69 & $16.686^{* * *}$ \\
Kontrol & 4.762 & $53.763^{* * *}$ \\
Percaya diri & 8.923 & $84.359^{* * *}$ \\
\hline
\end{tabular}

Ket : ${ }^{* *}=$ signifikan di $\alpha 1 \%,{ }^{*}=$ signifikan di $\alpha 5 \%, *=$ signifikan di $\alpha 10 \%$

Sumber : Hasil data olahan

Tabel 7

Profil Psikologi untuk Masing-masing Cluster

\begin{tabular}{lcc}
\hline \hline \multicolumn{1}{c}{ Karakteristik } & $\begin{array}{c}\text { Cluster 1 } \\
\text { Confident big trader } \\
\mathbf{N}=\mathbf{1 0 6}\end{array}$ & $\begin{array}{c}\text { Cluster 2 } \\
\text { Loss Averse small trader } \\
\mathbf{N}=\mathbf{9 4}\end{array}$ \\
\hline $\begin{array}{l}\text { Horizon investasi jangka } \\
\text { panjang/pendek }\end{array}$ & $3.2338^{* * *}(0.040187)$ & $3.4662^{* * *}(0.040108)$ \\
Kontrol & & \\
Percaya diri & $5.0064^{* * *}(0.34181)$ & $4.5832^{* * *}(0.30541)$ \\
\hline
\end{tabular}

Ket : ( ) menunjukkan standar deviasi; kategori rating 1 = rendah, 7 = tinggi.

$* * *=$ signifikan di $\alpha 1 \%$, ** = signifikan di $\alpha 5 \%$, * = signifikan di $\alpha 10 \%$

Sumber : Hasil data olahan

Tabel 7 adalah tabel perilaku untuk masing-masing cluster. Berdasarkan tabel 7, terlihat bahwa baik cluster 1 maupun cluster 2 memiliki horizon investasi yang pendek, dan kontrol serta percaya diri yang tinggi. Selanjutnya penulis juga melakukan crosstab untuk statistik deskriptif dari masingmasing cluster sebagai berikut:

Tabel 8

Statistik Deskriptif Cluster

\begin{tabular}{lccc}
\hline \hline & & \multicolumn{2}{c}{ Cluster Number of case } \\
\cline { 4 - 4 } & Rata-rata & $\begin{array}{c}\text { Confident } \\
\text { Big trader } \\
\mathbf{( n = 1 0 6 )}\end{array}$ & $\begin{array}{c}\text { Loss Averse } \\
\text { Small Trader } \\
\mathbf{( n = 9 4 )}\end{array}$ \\
\hline $\begin{array}{l}\text { Jenis Kelamin } \\
\text { Pria }\end{array}$ & & & \\
Wanita & $65.5 \%$ & $76(71.70 \%)$ & $55(58.51 \%)$ \\
\hline Umur & $34.5 \%$ & $30(28.30 \%)$ & $39(41.49 \%)$ \\
\hline 20 thn & & & \\
20-30 thn & 0 & 0 & 0 \\
$40-50$ thn & $20.5 \%$ & $25(23.58 \%)$ & $16(17.02 \%)$ \\
$>50$ thn & $75 \%$ & $76(71.70 \%)$ & $74(78.72 \%)$ \\
\hline
\end{tabular}




\begin{tabular}{|c|c|c|c|}
\hline $\begin{array}{l}\text { Status Pernikahan } \\
\text { Menikah } \\
\text { Belum menikah }\end{array}$ & $\begin{array}{c}99 \% \\
1 \% \\
\end{array}$ & $\begin{array}{c}105(99.06 \%) \\
1(0.94 \%) \\
\end{array}$ & $\begin{array}{c}93(98.94 \%) \\
1(1.06 \%) \\
\end{array}$ \\
\hline \multicolumn{4}{|l|}{ Pendidikan } \\
\hline SMU & 0 & 0 & 0 \\
\hline Diploma & $1 \%$ & $1(0.94 \%)$ & $1(5.06 \%)$ \\
\hline S1 & $85.5 \%$ & $96(90.57 \%)$ & $75(75.79 \%)$ \\
\hline S2 & $13.5 \%$ & $9(8.49 \%)$ & $18(19.15 \%)$ \\
\hline S3 & 0 & 0 & 0 \\
\hline \multicolumn{4}{|l|}{ Berapa lama investasi } \\
\hline$<1$ bulan & 0 & 0 & 0 \\
\hline 1 bulan -1 tahun & $13 \%$ & $5(4.72 \%)$ & $21(22.34 \%)$ \\
\hline 1 tahun -3 tahun & $83 \%$ & $95(89.62 \%)$ & $71(75.53 \%)$ \\
\hline$>3$ tahun & $4 \%$ & $6(5.66 \%)$ & $2(2.13 \%)$ \\
\hline \multicolumn{4}{|l|}{ Metode transaksi } \\
\hline Bertemu langsung dengan broker & $21.5 \%$ & $29(27.36 \%)$ & $14(14.89 \%)$ \\
\hline e-trading & $78.5 \%$ & $77(72.64 \%)$ & $80(85.11 \%)$ \\
\hline Melalui telepon dengan broker & 0 & 0 & 0 \\
\hline \multicolumn{4}{|l|}{ Nilai Portfolio } \\
\hline$<\operatorname{Rp} 1.000 .000$ & 0 & 0 & 0 \\
\hline $\operatorname{Rp} 1.000 .000-\operatorname{Rp} 10.000 .000$ & $0.5 \%$ & 0 & $1(1.06 \%)$ \\
\hline $\operatorname{Rp} 10.000 .001-\operatorname{Rp} 30.000 .000$ & $22.5 \%$ & $12(11.32 \%)$ & $33(35.11 \%)$ \\
\hline $\operatorname{Rp} 30.000 .001-\operatorname{Rp} 50.000 .000$ & $52.5 \%$ & $59(55.66 \%)$ & $46(48.94 \%)$ \\
\hline $\operatorname{Rp} 50.000 .001-\operatorname{Rp} 100.000 .000$ & $24 \%$ & $34(32.08 \%)$ & $14(14.89 \%)$ \\
\hline$>\operatorname{Rp} 100.000 .000$ & $0.5 \%$ & $1(0.94 \%)$ & 0 \\
\hline \multicolumn{4}{|l|}{ Jumlah transaksi per tahun } \\
\hline $1-4$ transaksi & 0 & 0 & 0 \\
\hline $5-8$ transaksi & $25 \%$ & $15(14.15 \%)$ & $35(37.23 \%)$ \\
\hline $9-12$ transaksi & $70.5 \%$ & $86(81.13 \%)$ & $55(58.51 \%)$ \\
\hline$>12$ transaksi & $4.5 \%$ & $5(4.72 \%)$ & $4(4.26 \%)$ \\
\hline \multicolumn{4}{|l|}{$\begin{array}{l}\text { Seberapa sering memperhatikan nilai } \\
\text { investasi }\end{array}$} \\
\hline Sehari sekali & $46 \%$ & $59(55.66 \%)$ & $33(35.11 \%)$ \\
\hline Setiap 2-3 hari sekali & $48.5 \%$ & $44(41.52 \%)$ & $53(56.38 \%)$ \\
\hline Seminggu sekali & $5.5 \%$ & $3(2.83 \%)$ & $8(8.51 \%)$ \\
\hline Sebulan sekali & 0 & 0 & 0 \\
\hline 3 bulan sekali & 0 & 0 & 0 \\
\hline$>3$ bulan sekali & 0 & 0 & 0 \\
\hline \multicolumn{4}{|l|}{ Jenis Investasi beli } \\
\hline Saham perusahaan unggulan (bluechip) & $73.5 \%$ & $102(96.23 \%)$ & $45(47.87 \%)$ \\
\hline Saham perusahaan kecil/menengah & $24.5 \%$ & $4(3.77 \%)$ & $45(47.87 \%)$ \\
\hline Reksadana & $2 \%$ & 0 & $4(4.26 \%)$ \\
\hline \multicolumn{4}{|l|}{ Alasan pembelian } \\
\hline Karyawan perusahaan yang bersangkutan & 0 & 0 & 0 \\
\hline Rekomendasi teman & $2.5 \%$ & $1(0.94 \%)$ & $4(4.25 \%)$ \\
\hline Rekomendasi broker & $88.5 \%$ & $91(85.85 \%)$ & $86(91.49 \%)$ \\
\hline Potensi perkembangan saham tersebut & $9 \%$ & $14(13.21 \%)$ & $4(4.26 \%)$ \\
\hline
\end{tabular}


Jenis investasi jual

Saham perusahaan unggulan (bluechip) $\quad 75.5 \% \quad 99(93.40 \%) \quad 52(55.32 \%)$

Saham perusahaan kecil/menengah $\quad 24.5 \% \quad 7(6.6 \%) \quad 42(44.68 \%)$

Reksadana

0

0

0

Alasan penjualan

Membutuhkan dana tunai

0

0

0

Kinerja saham yang buruk

$13 \% \quad 13(12.26 \%) \quad 13(13.83 \%)$

Kinerja manajemen perusahaan yang $\quad 77.5 \% \quad 80(75.47 \%) \quad 75(79.79 \%)$

buruk

$9.5 \%$

$13(12.27 \%)$

$6(6.38 \%)$

Profit taking

\section{Sumber informasi}

Internet

$33.5 \%$

$37(34.91 \%)$

$30(31.91 \%)$

Broker

$54.5 \%$

$52(49.06 \%)$

$57(60.64 \%)$

Televisi

$8.5 \%$

$12(11.32 \%)$

$5(5.32 \%)$

Teman dan kolega

$3.5 \%$

Laporan keuangan perusahaan

0

Surat kabar

Rumor

0

0

Seberapa sering membaca laporan

keuangan perusahaan yang

dipublikasikan?

Selalu

$\begin{array}{ccc}3 \% & 6(5.66 \%) & 0 \\ 77.5 \% & 95(89.62 \%) & 60(63.83 \%) \\ 19.5 \% & 5(4.72 \%) & 34(36.17 \%)\end{array}$

Sering

Kadang-kadang

0

Jarang

0

0

0

Tidak pernah

Komposisi portfolio investasi

Saham unggulan/bluechip

$39.74 \%$

$47.66 \%$

$2(2.13 \%)$

Saham perusahaan kecil/menengah

$35.73 \%$

$35.16 \%$

$24.53 \%$

$17.18 \%$

$30.81 \%$

Reksadana

Jumlah transaksi rata-rata responden

Dari tabel 8 terlihat bahwa responden pria lebih banyak daripada wanita, sedangkan kisaran usia responden rata-rata berusia antara 30-40 tahun. Berdasarkan status pernikahan, rata-rata responden sudah berstatus menikah. Berdasarkan pendidikan terakhir, rata-rata responden mengenyam pendidikan S1. Rata-rata responden bekerja sebagai pegawai swasta dan rata-rata mereka sudah bekerja selama 10-15 tahun.

Rata-rata responden sudah berinvestasi selama 1-3 tahun, dengan metode transaksi paling sering digunakan oleh responden adalah model e-trading. Nilai portfolio investasi responden rata-rata antara Rp $30 \mathrm{jt}$ -Rp $50 \mathrm{jt}$. sebanyak 9-12 kali setahun. Rata-rata responden akan mengecek nilai portfolio setiap 2-3 hari sekali.

Cluster 1 - Confident Big Trader. Investor dalam cluster ini memiliki tingkat kontrol dan percaya diri yang tinggi dengan horizon investasi jangka pendek. Kelompok ini memiliki lebih banyak anggota pria $(71.7 \%)$. Sebanyak $89,62 \%$ investor dalam kelompok ini sudah bertransaksi antara 1-3 tahun (lebih besar dari rata-rata sampel 83\%), dimana $72,64 \%$ menggunakan metode $e$ trading untuk bertransaksi dan sekitar $27,36 \%$ yang menggunakan jasa broker.

Sekitar 55,66\% investor dalam kelompok ini memiliki nilai portfolio antara 
Rp 10.000.001-Rp 30.000.000 (lebih besar dari rata-rata sampel 52,5\%), dan 32,08\% memiliki portfolio antara $\mathrm{Rp} 30.000 .001-\mathrm{Rp}$ 50.000.000 (lebih besar dari rata-rata sampel 24\%). Mereka cukup sering melakukan transaksi, dimana 81,13\% melakukan 9-12 kali transaksi setahun (lebih besar dari ratarata sampel $70,5 \%$ ). Investor dalam kelompok ini cukup sering memantau perkembangan nilai investasi mereka, dimana sekitar $55,66 \%$ akan mengecek sehari sekali (lebih besar dari rata-rata sampel $46 \%$ ) dan $41,52 \%$ mengecek setiap 2-3 hari sekali. Sumber informasi yang menjadi pertimbangan investor dalam kelompok ini adalah broker $(49,06 \%)$ dan internet $(34,91 \%)$ (lebih besar dari rata-rata sampel 33,5\%). Sebesar 89,62\% investor kelompok ini juga sering membaca laporan keuangan yang resmi dipublikasikan oleh perusahaan (lebih besar dari ratarata sampel $77,5 \%)$. Komposisi portfolio mereka terdiri dari saham unggulan/ bluechip 47,66\% (lebih besar dari rata-rata sampel $39,74 \%)$, saham perusahaan kecil/ menengah $35,16 \%$ dan sisanya reksadana $17,18 \%$.

Investor dalam kelompok ini tergolong investor yang bersifat irasional, karena memiliki ciri-ciri kepercayaan diri yang tinggi, senang memiliki kontrol atas investasinya, yang dimanifestasikan dalam seringnya mengecek nilai investasi setidaknya sehari sekali, serta memiliki portfolio yang cederung besar nilainya, mungkin ini karena anggota kelompok ini sebanyak 23,58\% berumur antara 20-30 tahun (lebih besar dari ratarata sampel), relatif masih muda dan berani mengambil risiko yang lebih besar. Komposisi portfolio mereka lebih banyak saham perusahaan ungggulan.

Cluster 2-Loss Averse Small Trader. Kelompok investor ini memiliki tingkat kontrol dan percaya diri yang tinggi dengan horizon investasi yang jangka pendek, di mana pria sebesar $58,51 \%$ lebih banyak dari pada wanita. Sekitar $75,53 \%$ sudah memiliki pengalaman investasi antara 1-3 tahun, namun masih banyak yang baru berinvestasi antara 1 bulan-1 tahun (22,34\%) (lebih besar dari rata-rata sampel 13\%). Metode transaksi yang sering digunakan oleh kelompok ini adalah e-trading $(85,11 \%)$ (lebih besar dari rata-rata sampel 78,5\%), lebih banyak daripada menggunakan jasa broker. Namun nilai portfolio investor kelompok ini cenderung lebih kecil daripada investor cluster 1. Nilai portfolio senilai $\mathrm{Rp}$ 10.000.001-Rp 30.000.000 (48,94\%), dan antara Rp 1.000.001-Rp 10.000.000 (35,11\%) (lebih besar dari rata-rata sampel 22,5\%).

Kelompok ini cukup sering melakukan transaksi dimana 37,23\% melakukan transaksi antara 5-8 kali setahun (lebih besar dari rata-rata sampel 25\%) dan 58,51\% melakukan transaksi sebanyak 9-12 kali setahun. Sumber informasi penting bagi kelompok ini adalah broker $(60,64 \%)$ (lebih besar dari rata-rata sampel $54,5 \%$ ) dan internet $(31,91 \%)$. Kelompok ini cukup sering membaca laporan keuangan perusahaan yang dipublikasi $(63,83 \%)$, namun sekitar $36,17 \%$ yang mengaku hanya kadang-ka dang membaca laporan keuangan. Kompo sisi portfolio investor kelompok ini terdiri dari saham unggulan/bluechip 30,81\%, saham perusahaan kecil/menengah 36,37\% (lebih besar dari rata-rata sampel 35,73\%) dan sisanya reksadana 32,82\% (lebih besar dari rata-rata sampel 24,53\%).

Investor dalam kelompok ini juga merupakan investor yang bersifat irasional, karena memiliki ciri-ciri kepercayaan diri serta kontrol yang tinggi, namun dengan portfolio yang cenderung lebih kecil nilainya dari pada nilai investasi kelompok 1 . Komposisi portfolio mereka juga lebih merata, antara saham perusahaan unggulan, saham perusahaan kecil dan reksadana. Ini mungkin disebabkan karena 78,72\% berusia dibawah 40 tahun, dan pada tahap ini mereka relatif tidak bisa menanggung kerugian besar jika nilai investasi turun.

\section{Preferensi terhadap Sumber Informasi}

Pada responden juga ditanyakan bagaimana preferensi mereka terhadap sumbersumber informasi antara lain internet, broker, televisi, teman dan kolega, laporan keua- 
ngan, surat kabar dan rumor. Hasilnya investor kelompok confident big trader memilih preferensi 1) internet, 2) laporan keuangan, 3) broker, 4) teman dan kolega, 5) surat kabar, 6) televisi dan 7) rumor, sedangkan investor kelompok loss averse small trader memilih 1) internet, 2) broker, 3) laporan keuangan, 4) teman dan kolega, 5) surat kabar, 6) televisi dan 7) rumor. Berikut ini adalah tabel preferensi investor terhadap sumber informasi.

Tabel 9

Preferensi investor terhadap sumber informasi

\begin{tabular}{clccccccc}
\hline $\begin{array}{l}\text { Cluster } \\
\begin{array}{l}\text { Number } \\
\text { of Case }\end{array}\end{array}$ & Internet & Broker & Televisi $\begin{array}{c}\text { Teman } \\
\text { dan } \\
\text { kolega }\end{array}$ & $\begin{array}{c}\text { Laporan } \\
\text { keuangan }\end{array}$ & $\begin{array}{c}\text { Surat } \\
\text { kabar }\end{array}$ & Rumor \\
\hline 1 & Mean & 5.87 & 5.27 & 4.47 & 5.10 & 5.56 & 5.02 & 4.24 \\
& $\mathrm{~N}$ & 106 & 106 & 106 & 106 & 106 & 106 & 106 \\
& Std. Deviation & .490 & .577 & .584 & .446 & .502 & .589 & .659 \\
2 & Mean & 5.40 & 5.26 & 4.18 & 4.83 & 4.89 & 4.60 & 3.99 \\
& $\mathrm{~N}$ & 94 & 94 & 94 & 94 & 94 & 94 & 94 \\
& Std. Deviation & .573 & .576 & .489 & .402 & .438 & .556 & .622 \\
Total & Mean & 5.65 & 5.26 & 4.33 & 4.97 & 5.24 & 4.83 & 4.12 \\
& $\mathrm{~N}$ & 200 & 200 & 200 & 200 & 200 & 200 & 200 \\
& Std. Deviation & .577 & .576 & .560 & .446 & .579 & .609 & .653 \\
\hline
\end{tabular}

Sumber : Hasil olahan data, kategori rating 1 = Tidak Bermanfaat, 7 = Sangat Bermanfaat.

Dari tabel 9 terlihat bahwa kelompok I (confident big trader) lebih mengandalkan informasi dari internet dan laporan keuangan. Dari data tabel 9, diperoleh hasil bahwa kelompok ini lebih sering membaca laporan keuangan. Mereka cenderung memiliki keyakinan akan kemampuan mereka dalam memprediksi pergerakan saham melalui informasi yang mereka peroleh. Mereka cenderung memilih saham perusahaan unggulan yang menjadi perhatian publik, karena lebih gampang memperoleh informasi tentang perusahaan unggulan. Ini berkolaborasi dengan hasil penelitian Barber dan Odean (2008) serta Barber et al. (2009) yaitu investor individu cenderung membeli saham-saham yang menjadi perhatian publik (saham yang banyak diinformasikan dalam internet). Investor tipe ini akan lebih sering mengecek posisi portfolionya setidaknya sehari sekali, dan ini bisa dilihat dari data tabel 8, hal ini sesuai dengan hasil penelitian Glaser dan Weber (2007); Graham et al. (2009); Grinblatt dan Keloharju (2009).

\section{Tabel 10}

Rentang Skala Nilai Rata-Rata Preferensi terhadap Sumber Informasi

\begin{tabular}{ll}
\hline \hline Kelas Interval & \multicolumn{1}{c}{ Intepretasi } \\
\hline $1-1.8571$ & Sangat tidak bermanfaat \\
$1.8572-2.7143$ & Tidak bermanfaat \\
$2.7144-3.5715$ & Agak tidak bermanfaat \\
$3.5716-4.4287$ & Sedang \\
$4.4288-5.2859$ & Agak bermanfaat \\
$5.2860-6.1431$ & Bermanfaat \\
$6.1432-7$ & Sangat bermanfaat \\
\hline
\end{tabular}

Ket : Interval dibuat berdasarkan rumus rentang skala (Simamora, 2008)

Kelompok Loss averse small trader lebih mengandalkan informasi dari internet dan broker. Mereka lebih memilih internet dan broker untuk mencari informasi tentang saham yang sedang mereka incar. Ini sesuai dengan hasil penelitian Wood dan Zaichkowsky (2004), bahwa kelompok investor loss averse akan lebih mengandalkan internet dan nasehat orang lain dalam mengevaluasi portfolionya. 
Berdasarkan profil investor yang dihasilkan, maka peneliti mencoba untuk menyusun model aplikasi praktis untuk menentukan sikap perusahaan sekuritas dalam berhubungan dengan kelompok-kelompok investor ini, peneliti menggunakan model yang dibuat oleh Pompian dan Longo (2005).

\section{Cluster 1 - Confident Big Trader}

Merupakan kelompok dengan anggota terbanyak $(n=106)$. Kelompok ini memiliki kepercayaan diri dan kontrol yang tinggi, dan merupakan kelompok yang aktif bertransaksi. Ini sesuai dengan hasil penelitian Barber dan Odean (Wood dan Zaichkowsky, 2004); Glaser dan Weber (2007), Graham et al. (2009); Grinblatt dan Keloharju (2009) bahwa investor dengan tingkat kepercayaan diri yang tinggi akan bertransaksi lebih sering. Mereka juga rajin mengecek posisi portfolio, dan memiliki saham perusahaan unggulan dengan proporsi lebih besar daripada kelompok lain. Mereka memiliki horizon investasi jangka pendek. Kelompok ini memiliki nilai portfolio yang besar dan memiliki pengalaman investasi lebih banyak. Kelompok ini lebih mengandalkan informasi dari internet dan laporan keuangan daripada sumber informasi lain. Cara komunikasi efektif dengan kelompok ini adalah dengan lebih menekankan pada isuisu kinerja saham, dan menawarkan informasi-informasi terkini tentang saham unggulan.

Dari profil psikologi, cluster ini memiliki bias overconfidence (bias kognitif), self control (bias emosional) dan kekayaan yang lebih tinggi (high wealth). Bias kelompok ini seimbang antara bias kognitif dan emosional, maka berdasarkan model Pompian dan Longo (2005), rekomendasi yang tepat untuk alokasi portfolionya adalah mengambil sikap moderat dan beradaptasi dengan bias kelompok ini (moderate and adapt). Disarankan agar kelompok ini lebih banyak berinvestasi dalam saham (dengan proporsi $\pm 60 \%$ ), obligasi (proporsi $\pm 35 \%$ ) dan kas (proporsi $\pm 5 \%$ ). Kalau dikaitkan dengan saham unggulan dan saham perusahaan kecil, maka disarankan lebih banyak proporsi dalam saham perusahaan unggulan (dengan proporsi $\pm 60 \%$ ) dan selebihnya saham kecil.

\section{Cluster 2 - Loss Averse Small Trader}

Merupakan kelompok yang memiliki lebih banyak investor berumur 30-40 tahun, dengan nilai investasi yang kecil. Mereka takut berinvestasi terlalu besar karena mereka tidak bisa menanggung risiko kehilangan uang terlalu banyak, mungkin karena mereka memiliki pertimbangan keluarga dan lain-lain serta mungkin karena kekurangan pengalaman investasi. Ini sesuai dengan penelitian sebelumnya mengenai bias loss aversion yang dibuat oleh Barber dan Odean (2011); Grinblatt dan Han (2005); Hens dan Vlcek (2011); Kyle et al. (2006); Kaustia (2004, 2010a, 2010b); Muermann dan Volkman (2006); Summers dan Duxbury (2007); Strahilevitz et al. (2011); Yao dan Li (2013). Horizon investasi kelompok ini jangka pendek. Kelompok ini juga memiliki kepercayaan diri dan kontrol yang tinggi. Mereka mengandalkan informasi dari internet dan broker. Komposisi portfolio mereka cenderung merata antara saham perusahaan unggulan, saham perusahaan kecil dan reksadana. Cara komunikasi yang efektif dengan kelompok ini adalah dengan menawarkan website dengan content yang selalu update dengan informasi terkini.

Dari profil psikologi, cluster ini memiliki bias overconfidence (bias kognitif), regret avoidance, loss aversion, self control (bias emosional) dan kekayaan yang lebih rendah (low wealth). Bias kelompok ini cenderung lebih banyak bersifat emosional, maka berdasarkan model Pompian dan Longo (2005), rekomendasi yang tepat untuk alokasi portfolionya adalah mengambil sikap moderat dan beradaptasi dengan bias kelompok ini (moderate and adapt), maka disarankan agar kelompok ini lebih banyak berinvestasi dalam saham (dengan proporsi $\pm 60 \%$ ), obligasi (proporsi $\pm 35 \%$ ) dan kas (proporsi 
$\pm 5 \%)$. Kalau dikaitkan dengan saham unggulan dan saham perusahaan kecil, maka disarankan lebih banyak proporsi dalam saham perusahaan unggulan (dengan proporsi $\pm 60 \%$ ) dan selebihnya saham kecil.

Visual deskripsi untuk kedua cluster sebagai berikut:



\section{Gambar 2 \\ Hasil penyesuaian model alokasi aset kedua cluster (Pompian dan Longo, 2005)}

\section{SIMPULAN DAN SARAN}

Dari penelitian ini bisa ditarik simpulan bahwa investor individu Indonesia cenderung bersifat irasional dalam berinvestasi, dimana mereka bisa digolongkan dalam 2 kelompok besar yaitu kelompok confident big trader yang memiliki rasa percaya diri serta kontrol yang tinggi, serta nilai portfolio besar dan kelompok kedua adalah kelompok loss averse small trader yang memiliki rasa percaya diri serta kontrol yang tinggi, dengan nilai portfolio yang kecil. Hasil ini mendukung teori Behavioral Finance yang dikemukakan oleh Barberis dan Thaler (2003), Shefrin (Johnson et al., 2005), Shiller (2005), dan Subrahmanyam (2008). Hasil ini juga sesuai dengan penelitian-penelitian sebelumnya seperti Odean (Johnson et al., 2005), Barber dan Odean (Barberis dan Thaler (2003), Wood dan Zaichkowsky (2004), 2011) dan lain-lain.

Saran untuk penelitian selanjutnya adalah sebaiknya menvalidasi pertanyaan mana yang lebih baik mewakili masing- masing karakteristik konseptual (seperti kontrol dan percaya diri). Saran lainnya adalah sebaiknya penelitian Behavioral Finance selanjutnya lebih dikaitkan dengan kinerja investasi atau pilihan saham.

Keterbatasan penelitian ini adalah investor yang diteliti untuk jangka waktu yang lebih lama dan dengan pertanyaan yang lebih mendetil. Untuk penelitian selanjutnya disarankan dengan jangka waktu yang lebih panjang.

\section{DAFTAR PUSTAKA}

Acharya, Viral V., dan Lasse Heje Pedersen. 2005. Asset Pricing with Liquidity Risk. Journal of Financial Economics 77(2):375410

Anderson, A. 2008. Trading and UnderDiversification. Working Paper, Institute for Financial Research, Stockholm.

Balasubramanian, S., P. Konana, dan N. M. Menon. 2003. Consumer Satisfaction in Virtual Environments: A Study of 
Online Investing. Management Science 49: 871-890.

Barber, B. M., dan T. Odean. 2008. All That Glitters: The Effect of Attention on the Buying Behavior of Individual and Institutional Investors. Review of Financial Studies 21: 785-818

Barber, B.M., dan T. Odean. 2011. The Behavior of Individual Investors. http:// ssrn.com/abstract $=1872211$. Diakses pada tanggal 26 Juli 2013.

Barber, B. M., T. Odean, dan N.Zhu. 2009. Systematic Noise. Journal of Financial Markets 12:447-469

Barber, B. M., Y. Lee, Y. Liu, dan T. Odean. 2005. Who Loses From Trade? Evidence From Taiwan. EFA 2005 Moscow Meetings Paper.

http://ssrn.com/abstract=529062. Diakses pada tanggal 26 Juli 2013.

Barber, B. M., Y. Lee, Y. Liu, dan T. Odean. 2007. Is the Aggregate Investor Reluctant to Realize Losses? Evidence from Taiwan. European Financial Management 13: 423-447.

Barber, B. M., Y. Lee, Y. Liu, dan T. Odean. 2009. Just How Much Do Individual Investors Lose by Trading? Review of Financial Studies 22: 609-632.

Barberis, N., dan Richard Thaler. 2003. A Survey of Behavioral Finance. Elsevier Science.

Barberis, N., dan Andrei Shleifer. 2003. Style Investing. Journal of Financial Economics 68: 161-199.

Barberis, N., Andrei Shleifer, dan Jeffrey Wurgler. 2005. Comovement. Journal of Financial Economics 75: 283-318.

Barberis, N., dan W. Xiong. 2009. What Drives the Disposition Effect? An Analysis of a Long-Standing Preference-Based Explanation. Journal of Finance 64(2): 751-784.

Benartzi, Shlomo., dan R.H. Thaler. 2007. Heuristics and Biases in Retirement Saving Behavior. Journal of Economic Perspectives 21(3): 81-104.
Bodie, Z., A. Kane, dan A.J. Marcus. 2008. Investment. $8^{\text {th }}$ ed. Mc-Graw-Hill Irwin. Los Angeles.

Bohlander, George W., dan Scott A. Snell. 2013. Principles of Human Resource Management. $16^{\text {th }}$ ed. South-Western: Cengage Learning.

Bollen, Nicolas P. B. 2007. Mutual Fund Attributes and Investor Behavior. Journal of Financial and Quantitative Analysis 42(3): 683-708.

Brown, P., N. Chappel, R. da Silva Rosa, dan T. Walter. 2006. The Reach of the Disposition Effect: Large Sample Evidence Across Investors Classes. International Review of Finance 6:42-78.

Camerer, Colin F., George Loewenstein, dan Matthew Rabin. 2004. Advances in Behavioral Economics. Princeton University Press and Russel Sage Foundation.

Calvet, L. E., J. Campbell, dan P. Sodini. 2007. Down or Out: Assessing the Welfare Costs of Household Investment Mistakes. Journal of Political Economy 115:707-747.

Calvet, L.E., J. Campbell, dan P. Sodini. 2009. Fight or Flight? Portfolio Rebalancing by Individual Investors. Quarterly Journal of Economics 124:301-348.

Cheng, Philip Y. K. 2007. The Trader Interaction Effect on hte Impact of Overconfidence on Trading Performance: An Empirical Study. Journal of Behavioral Finance 8(2): 59-69.

Chhabra, A. B. 2005. Beyond Markowitz: A Comprehensive Wealth Allocation Framework for Individual Investors. The Journal of Wealth Management 7(14): 8-34.

Coval, J. D., D .A. Hirshleifer, dan T. Shumway. 2005. Can Individual Investors Beat The Market?. Working Paper. Harvard University.

Døskeland, T., dan H. Hvide. 2011. Do Individual Investors Have Asymmetric Information Based on Work Experience? Journal of Finance 66:1011-1041. 
Dhar, R., dan N. Zhu. 2006. Up Close and Personal: Investor Sophistication and the Disposition Effect. Management Science 52:726-740.

Dorn, D., dan G. Huberman. 2005. Talk and Action: What Individual Investors Say and What They Do. Review of Finance 9: 437-481.

Dwikusumastuti, Erna. 2008. 3 Fase Karir. http://kesehatan.kompas.com-/read/2008/

01/29/19243252/3.Fase.Karier. Diakses pada tanggal 13 Januari 2013.

Feng, L., dan M. Seasholes. 2005. Do Investor Sophistication and Trading Experience Eliminate Behavioral Biases in Financial Markets? Review of Finance 9:305-351.

Frazzini, A. 2006. The Disposition Effect and Underreaction to News. Journal of Finance 61:2017-2046.

Ghoshal, Sumantra. 2005. Bad Management Theories Are Destroying Good Management Practices. Academic Management Learning Education 4(1): 75-91.

Glaser, M., dan M. Weber. 2007. Overconfidence and Trading Volume. Geneva Risk and Insurance Revue 32:1-36.

Graham, J. R., C. R. Harvey, dan H. Huang. 2009. Investor Competence, Trading Frequency, and Home Bias. Management Science 55: 1094-1196.

Grinblatt, M., dan Bing Han. 2005. Prospect Theory, Mental Accounting, and the Disposition Effect. Journal of Financial Economics 78: 311-339.

Grinblatt, M., dan M. Keloharju. 2009. Sensation Seeking, Overconfidence, and Trading Activity. Journal of Finance 64: 549-578.

Hens, T., dan M. Vlcek. 2011. Does Prospect Theory Explain the Disposition Effect? Journal of Behavioral Finance 12(3): 141157.

Hong, Harrison., dan Yu Jialin. 2009. Gone Fishin': Seasonality in Trading Activity and Asset Prices. Journal of Financial Markets 12(4): 672-702.

Huang, X. 2010. Industry Investment Experience and Stock Selection. Working
Paper, University of California, Berkeley.

Indonesia Economic Review (2004-2012).

Johnson, J., Gerard J. Tellis, dan Deborah J. MacInnis. 2005. Losers, Winners, and Biased Trades. Journal of Consumer Research 32(2): 324-329.

Kahneman, Daniel. 2003. A Perspective on Judgment and Choice: Mapping Bounded Rationallity. American Psychologist 58(9): 697-720.

Kamstra, Mark J., Lisa A. Kramer, dan Maurice D. Levi. 2010. Effects of Daylight-Saving Time Changes on Stock Market Volatility: A Comment. Psychological Reports 107(6):877-887.

Kaniel, R., G. Saar, dan S. Titman. 2008. Individual Investor Trading and Stock Returns. Journal of Finance 63:273-310.

Kaustia, M. 2004. Market-Wide Impact of the Disposition Effect: Evidence from IPO Trading Volume. Journal of Financial Markets 7:207-235.

Kaustia, M. 2010a. Disposition Effect in Behavioral Finance: Investors, Corporations, and Markets, H.K. Baker dan J.R.Nofsinger, eds. John Wiley \& Sons. Hoboken, New Jersey.

Kaustia, M. 2010b. Prospect Theory and the Disposition Effect. Journal of Financial and Quantitative Analysis 45: 791-812.

Kaustia, M., dan S. Knupfer. 2008. Do Investors Overweight Personal Experience? Evidence from IPO Subscriptions. Journal of Finance 63: 2679-2702.

Korniotis, G. M., dan A.Kumar. 2009. Do Older Investors Make Better Investment Decisions? Review of Economics and Statistics 93: 244-265.

Komite Ekonomi Nasional, Prospek Ekonomi Indonesia 2013.

Kyle, A., Hui Ou-Yang, dan Wei Xiong. 2006. Prospect Theory and Liquidation Decisions. Journal of Economic Theory 129: 273-285.

Lo, A.W. 2005. Reconciling Efficient Markets With Behavioral Finance: The Adaptive Markets Hypothesis. 
http://ssrn.com/ abstract=728864. Diakses pada tanggal 26 Juli 2013.

Mathis, Robert L., dan John H. Jackson. 2003. Human Resource Management., $10^{\text {th }}$ ed. Thomson South Western.

Moore, D., dan P.J. Healy. 2008. The Trouble with Overconfidence. Psychological Review 115: 502-517.

Muermann, A., dan J. Volkman. 2006. Regret, Pride and the Disposition Effect. Working Paper. The Wharton School.

Noe, Raymond A. 2010. Employee Training and Development. $5^{\text {th }}$ ed. McGraw-Hill International Edition.

Peng, L., dan W.Xiong. 2006. Investor Attention, Overconfidence, and Category Learning. Journal of Financial Economics 80: 563-602.

Pompian, M.M., dan J.M. Longo. 2004. A New Paradigm for Practical Appication of Behavioral Finance: Creating Investment Programs Based on Personality Type and Gender to Produce Better Investment Outcomes. The Journal of Wealth Management Fall 2004: 9-15.

Pompian, M.M., dan J.M. Longo. 2005. The Future of Wealth Management: Incorporating Behavioral Finance into Your Practice. Journal of Financial Planning 18(3): 58-72.

Robbins, Stephen P., dan Timothy A. Judge. 2013. Organizational Behavior. 15th $\mathrm{ed}$. Pearson Education.

Scheinkman, J., dan W. Xiong. 2003. Overconfidence and Speculative Bubbles. Journal of Political Economy 111:11831219.

Seasholes, M. S., dan G.Wu. 2007. Predictable Behavior, Profits and Attention. Journal of Empirical Finance 15: 590-610.
Seasholes, M. S., dan N. Zhu. 2010. Individual Investors and Local Bias. Journal of Finance 65: 1987-2010.

Seru, A., T. Shumway, dan N. Stoffman. 2010. Learning by Trading. Review of Financial Studies 23: 705-839.

Shiller, Robert J. 2003. From Efficient Markets Theory to Behavioral Finance. Journal of Economic Perspectives 17(1): 83104.

Shiller, Robert J. 2005. Irrational Exuberance. Princeton University Press.

Simamora, Bilson. 2008. Panduan Riset Perilaku Konsumen. PT Gramedia Pustaka Utama. Jakarta.

Strahilevitz, M., T. Odean, dan B. Barber. 2011. Once Burned, Twice Shy: How Naive Learning, Counterfactuals, and Regret Affect the Repurchase of Stocks Previously Sold. Journal of Marketing Research 48: s102-s120.

Subrahmanyam, A. 2008. Behavioral Finance: A Review and Synthesis. European Financial Management 14:12-29.

Summers, B., dan D. Duxbury. 2007. Unraveling the Disposition Effect: The Role of Prospect Theory and Emotions. Working Paper. Leeds University Business School.

Werner, Jon M., dan Randy L DeSimone. 2009. Human Resources Development. 5th ed. South-Western Cengage Learning.

Wood, R., dan J. L. Zaichkowsky. 2004. Attitudes and Trading Behavior of Stock Market Investors: A Segmentation Approah. The Journal of Behavioral Finance 5(13): 170-179.

Yao, J., dan D. Li. 2013. Prospect Theory and Trading Patterns. Journal of Banking and Finance 37(8): 2793-2805. 